\title{
Soil temperature responses to climate change along a gradient of upland-riparian transect in boreal forest
}

\author{
S . K. Oni ${ }^{1,4}$ - F. Mieres ${ }^{2}$ - M. N. Futter ${ }^{3}$ H. Laudon ${ }^{1}$
}

Received: 18 September 2016 / Accepted: 16 April 2017 / Published online: 11 May 2017

(C) The Author(s) 2017. This article is an open access publication

\begin{abstract}
There is growing evidence of climate change impacts on northern ecosystems. While most climate change studies base their assessments on air temperature, spatial variation of soil temperature responses have not been fully examined as a metric of climate change. Here we examined spatial variations of soil temperature responses to an ensemble of regional climate model (RCM) projections at multiple depths in upland and riparian zones in the Swedish boreal forest. Modeling showed a stronger influence of air temperature on riparian soil temperature than was simulated for upland soils. The RCM ensemble projected a warming range of $4.7-6.0{ }^{\circ} \mathrm{C}$ in riparian and $4.3-5.7{ }^{\circ} \mathrm{C}$ in upland soils. However, soils were slightly colder in the riparian zone during winter. While the historical record showed that upland soils are about $0.4{ }^{\circ} \mathrm{C}$ warmer than the riparian soils, this may be reversed in the future as model projections showed that on an annual basis, riparian soils might be slightly warmer by 0.2 to $0.4{ }^{\circ} \mathrm{C}$ than upland soils. However, upland soils could warm up earlier (April) compared to riparian soils (May).
\end{abstract}

Electronic supplementary material The online version of this article (doi:10.1007/s10584-017-1977-1) contains supplementary material, which is available to authorized users.

S. K. Oni

soni@trentu.ca; oni.stephen@yahoo.com

1 Department of Forest Ecology and Management, Swedish University of Agricultural Sciences, SE-901 83 Umeå, Sweden

2 Division of Land and Water Resources Engineering, KTH Royal Institute of Technology, SE-10044 Stockholm, Sweden

3 Department of Aquatic Sciences and Assessment, Swedish University of Agricultural Sciences, SE-750 07 Uppsala, Sweden

4 Department of Biology, Trent University, Peterborough, Ontario, Canada 


\section{Introduction}

There is increasing evidence of climate change impacts in the boreal forest and other snow dominated northern ecosystems (Barnett et al. 2005; Brown and Robinson 2011; Koca et al. 2006). Projections of possible future climate change impacts in northern ecosystems are necessary as the boreal forest exerts an important control on regional biogeochemical cycles with global consequences. For example, the boreal biome (above $50^{\circ} \mathrm{N}$ latitude) represents about $29 \%$ of the world forest ecosystems (Apps et al. 1993) and stores up to $500 \mathrm{Gt}$ of carbon (more than $30 \%$ of terrestrial carbon), making it an important component of the global carbon system (Batjes 1996; Kasischke 2000; Pan et al. 2011). While there is no consensus on the magnitude of future changes in this northern region, historical records show that recent decades are warmer than the last century (Karlsson et al. 2014). The International Panel on Climate change (IPCC) suggests that global mean air temperature may rise by up to $6{ }^{\circ} \mathrm{C}$ by the end of the century (Solomon 2007). In addition to warmer air temperature that can extend growing season length and alter plant community composition (Charles and Dukes 2009), climate change would shift precipitation patterns toward rainfall dominance (Berghuijs et al. 2014) and a decrease in winter snow cover (Brown and Robinson 2011) in northern regions. However, there is a lack of knowledge about coupling/decoupling of soil-air temperature responses to a changing climate as routine monitoring in most regions does not adequately include measurement of soil temperature at a small spatial scale that will reflect landscape heterogeneity.

Boreal regions are characterized by long dormant seasons during the winter snow accumulation period, and spring melt represents the largest hydrological event that can account for more than half of annual water fluxes (Laudon et al. 2004). Any changes in snow accumulation could reduce the amplitude of spring melt, and the resulting loss of the insulating effect of snow can also increase the depth of soil frost (Henry 2008). Change in soil freeze-thaw cycles as a result of alterations in energy flow could have large effects on hydrological and biogeochemical processes (Euskirchen et al. 2007) and must be accounted for to constrain uncertainty in biogeochemical modeling of future conditions. Warmer soil temperature could have positive impacts on boreal forest productivity (Strömgren and Linder 2002) as well as plant community and soil composition (Charles and Dukes 2009; Pumpanen et al. 2012; Thakur et al. 2014). However, adverse effects of changes in soil temperature have also been reported on below-ground processes including decreased soil aggregate stability (Oztas and Fayetorbay 2003), increased nutrient leaching (Fitzhugh et al. 2001), higher root mortality (Tierney et al. 2001), greater rates of soil organic matter mineralization (Davidson and Janssens 2006), hydrological flow path alteration, increased soil microbial respiration, and cell wall lysis (Kreyling et al. 2013) among others.

Understanding the riparian-upland connection is important for water quality management (Jencso et al. 2010; Vidon et al. 2010). The riparian zone is the transition point between upland and aquatic ecosystems; it controls hydrologic connectivity both laterally along hillslopes and vertically down the soil profile (Grabs et al. 2012; Ledesma et al. 2015) as well as retention and transport of solutes (Luke et al. 2007). During high flow events, there can be an exponential increase in the lateral flux of water to streams as groundwater rises to more hydraulic conducting soil layers (Lyon et al. 2011; Peralta-Tapia et al. 2015). However, this lateral movement of water and solutes usually occur within a dominant source layer, a shallow and narrow depth range in riparian soil profile (Ledesma et al. 2015). This can impact both the hydrological and biogeochemical pathways along upland-riparian transect (Winterdahl et al. 2011). 
Several models have been used to simulate soil temperature in different environments. For example, Zheng et al. (1993) used a simple model to successfully simulate subsurface energy while Kang et al. (2000) showed that a hybrid model incorporating topography, canopy, and ground litter could better represent the empirical relationships between air and soil temperature. Bond-Lamberty et al. (2005) showed the relative importance of incorporating changes in forest canopy and leaf area index in improving soil temperature simulations. Recent work by Jungqvist et al. (2014) assessed possible future change in upland forest soil temperature dynamics by extending the model of Rankinen et al. (2004). However, simple models are evolving into models of varying complexities as the need to assess the impact of climate change on soil temperature becomes important in soil biogeochemistry (Kurylyk et al. 2013). One of such complex model is the coupled heat and mass transfer model for the soil-plant-atmosphere system (COUP). The COUP model is a physically based 1D model of soil temperature based on soil properties (Jansson 2012) and has been widely applied to simulate the behavior of boreal forest soils (Fröberg et al. 2006; Gustafsson et al. 2004; Hollesen et al. 2011).

The objectives of this study were to (1) use upland-riparian soils to assess variations in soil thermal capacity along a gradient of drier-wetter soils, and (2) evaluate how this could translate to soil temperature responses under an ensemble of plausible future climate conditions. To do this, we utilized long-term measurements of soil temperature at a series of depths at upland and riparian sites in a small catchment in the Swedish boreal forest.

\section{Method}

\subsection{Study site description}

The soil temperature modeling was conducted using long-term data from Svartberget $\left(64^{\circ} 16^{\prime} \mathrm{N}\right.$, $19^{\circ} 46^{\prime} \mathrm{E}$ ), an unmanaged boreal catchment nested within Krycklan Study Catchment in northern Sweden (http://www.slu.se/Krycklan). This well-instrumented research catchment is used for hypothesis testing, as well as experimental and process-driven research needed to advance our scientific knowledge and test management options in boreal forests (Laudon et al. 2013). The soils in the catchment are predominantly podzols underlain by quaternary till deposits of low permeability with organic histosols found in the riparian areas lining most streams (Ledesma et al. 2016). Elevation of the study site is approximately $250 \mathrm{~m}$ above sea level.

The climate is a cold temperate humid type with persistent snow cover during the winter season. The 30-year mean annual temperature (1981-2010) was $1.8^{\circ} \mathrm{C}$ with mean of -9.5 and $+14.7{ }^{\circ} \mathrm{C}$ in January and July, respectively. The 30 -year mean annual precipitation was $614 \mathrm{~mm} \mathrm{yr}^{-1}$ of which $50 \%$ contributes to stream flow. Snow generally begins to accumulate in early November, with a maximum snow depth of up to $120 \mathrm{~cm}$ occurring in early March. The average duration of snow cover is 167 days but has declined since 1980 by on average 0.5 days per year (Laudon and Ottosson-Löfvenius 2015). The region is characterized by high flow rates especially during rapid snowmelt.

Topography influences the landscape structure and hydrologic connectivity in the study area (Grabs et al. 2012). Riparian zones are located in low lying areas close to the stream and have shallow groundwater. Hillslope monitoring sites were instrumented in 1996 along a transect of upland-riparian hydrological flowpaths (Petrone et al. 2007). Two representative sites, arranged parallel to groundwater flow at $4 \mathrm{~m}$ ( $R$-riparian profile) and $22 \mathrm{~m}$ ( $U$ - upland profile) from the stream, were used for assessing soil temperature profiles (Fig. 1). Each of the 
profiles is instrumented to measure soil water content (Laudon et al. 2004), water isotopic composition (Peralta-Tapia et al. 2015), soil water chemistry (Ledesma et al. 2016; Oni et al. 2013), and TO3R NTC thermistor sensors recorded hourly using Campbell scientific data logger (CR1000).

\subsection{Soil temperature modeling}

In this study, we applied the coupled heat and mass transfer model for soil-plant-atmosphere systems (COUP model) to two soil profiles in the Svartberget catchment (Fig. 1). COUP model is a physically based model of soil-vegetation-atmosphere (SVAT) transfer of heat and

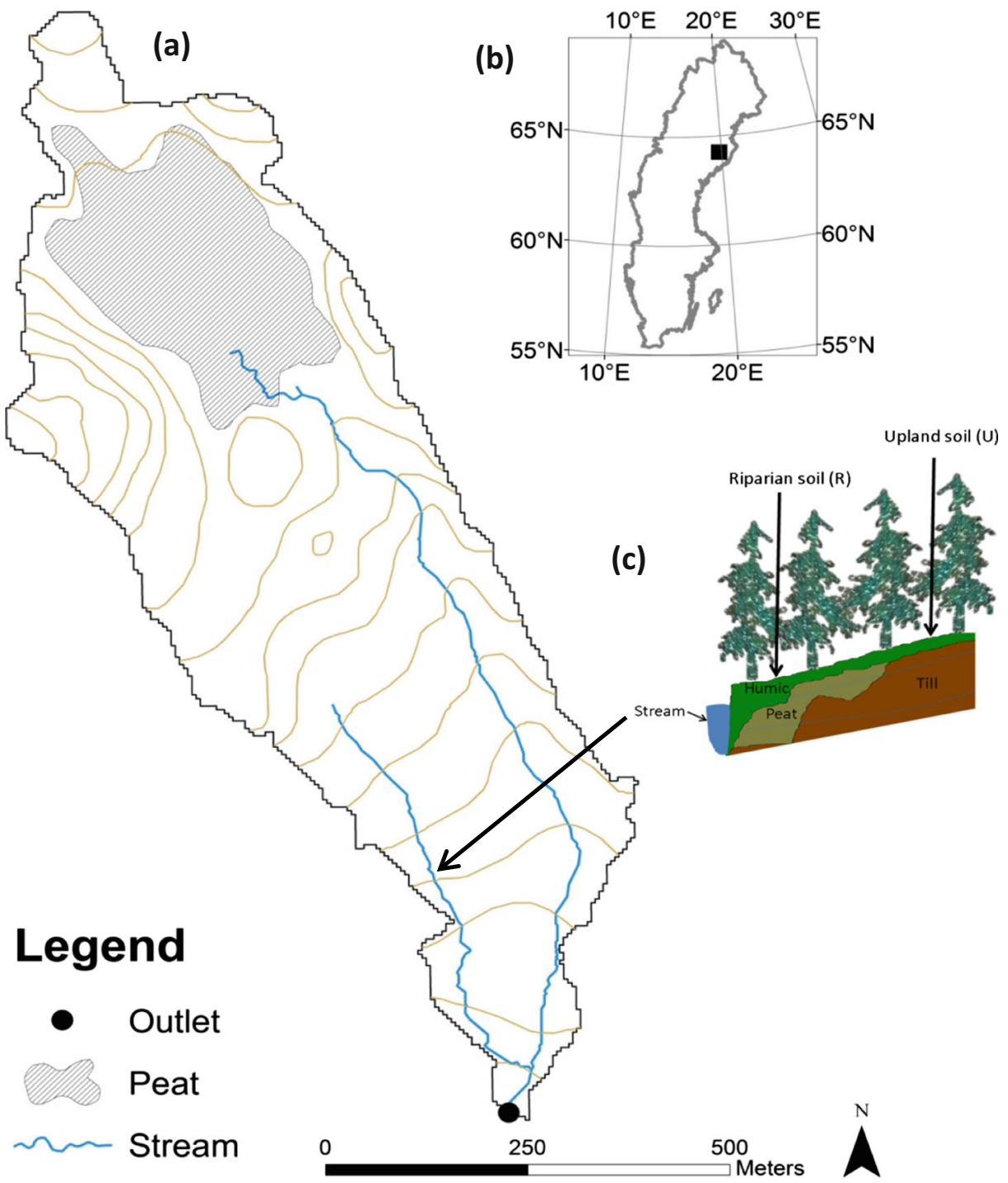

Fig. 1 Map of Svartberget catchment (a) in northern Swedish boreal forest (b) and its riparian $(R)$ and upland $(U)$ transects where soil temperature were measured along the upland-riparian gradient (c) 
water flows across a soil profile (Jansson and Karlberg 2011). Though the model was originally developed to simulate water and heat flows in forest soils, it now consists of different coupled modules including soil nitrogen and carbon processes. However, we only focused on heat flow processes in this study. The COUP model is based on the principle of law of conservation of mass and energy. This allows the model to properly account for heat flux across the soil profile as a sum of conduction and convection terms (Jansson and Karlberg 2011). The latter helped to account for high flow rates and heavy snowmelt infiltration that characterize the study area.

Model setup prior to calibration included setting up base files, parameters, and switches in accordance with the COUP reference manual (Jansson and Karlberg 2011). Soils were calibrated as vertical arrays of three layers $(10,20$, and $60 \mathrm{~cm}$ depths) in the riparian and $(12,20$, and $50 \mathrm{~cm}$ depths) in the upland soil profiles. Soil profiles were parameterized using field data from Nordén (1991). Heat exchange in the upper soil layer is dependent on snow processes and air temperature. Therefore, boundary conditions for the uppermost soil layers are dependent on soil evaporation, snow, and radiation processes while boundary conditions for lower soil layers were dependent on soil heat capacity that can be conducted to the surface. These boundaries were set up according to Metzger et al. (2015). Both thermal soil conductivity and snow density are important in the uppermost soil layers where snow insulation is a function of global radiation. Evaporation from soil surfaces was calculated using the PenmanMonteith empirical approach. An explicit single big leaf was considered for water interception and evapotranspiration purposes while snow pack was treated as homogenous layer. New snow density was estimated as a linear function of air temperature and snow densification as a function of ice and liquid contents. Snow surface temperature was calculated as a function of the energy balance. These processes are fully described in Jansson and Karlberg (2011).

\subsubsection{Model calibration, validation, and projections}

We calibrated the COUP model using available long-term air temperature $\left({ }^{\circ} \mathrm{C}\right)$ and precipitation (mm) series, global radiation $\left(\mathrm{J} \mathrm{s}^{-1} \mathrm{~m}^{-2}\right)$, air humidity $(\%)$, and windspeed $\left(\mathrm{m} \mathrm{s}^{-1}\right)$. Both air temperature and precipitation were available from the weather station at Svartberget while other data were available at the nearby $(10 \mathrm{~km})$ Degerö catchment. Consistent, good quality soil temperature data were available for both profiles from 2009 to 2014 onward. Therefore, the model was first calibrated against observed data (20092014) from the upland profile to define ranges of soil thermal and snowpack-related parameters which were later used for Monte Carlo simulations of parameter combinations (Supp 1). This also helped to test if the parameterization in the upland could produce credible simulations of riparian soil temperature profiles. The adjustments made to the riparian parameterization are listed in Supp 1. However, the parameters that were utilized in the subsequent Monte Carlo runs (Supp 1) included critical depth snow cover parameter that defines the thickness of snow height that covers the soil and density coefficient mass, which defined the mass of snow density as a function of liquid and ice content in old snow pack. Thermal conductivity was also varied as this parameter is dependent on solid soils and moisture that varies across the gradient of organic-mineral layers. In riparian site for example, thermal conductivity function for organic matter in unfrozen soil and temperature sensitivity coefficient were utilized. The latter is the exponential function associated with heat generation due to biological activity in the soil. In the upland soil, we also varied the soil thermal conductivity function in unfrozen sand, the organic layer thickness, and the 
infiltrating water temperature difference to air temperature for convective heat transport to the soil (Supp 1).

The calibration process followed the GLUE methodology (Beven and Binley 1992) using uniform prior distributions of calibration parameters. The model was validated using data collected in 2007 from the riparian profile so as to test model efficiency in simulating soil temperature under present day conditions. More detailed information about the COUP model, parameterization, set up, and applications can be found elsewhere (Jansson and Karlberg 2011). To assess potential climate change impacts, we used outputs from an ensemble of 15 regional climate models (RCM) run under the A1B emission scenario (Supp 2). Each RCM was bias corrected for precipitation and air temperature data using distribution mapping method (see Oni et al. 2014, 2015). Bias correction was based on monthly values which were estimated from daily weather series (1981-2010) available from the Svartberget catchment. First, RCMs precipitation and air temperature data for reference (1981-2010) and future (2061-2090) conditions were obtained by averaging eight RCM grids close to the catchment center. Bias corrections were performed by adjusting the cumulative distribution function (CDF) of RCM reference period (1981-2010) to CDF of the observed series for the same period. We then applied the relationship to the CDF of future RCM (2061-2090). The calibrated COUP model was run with bias corrected series to simulate comparable present day RCM simulations (1981-2010) and then future RCMs projections (2061-2010) for effective comparison. More information about the bias correction procedure can be found in Supp 2 or elsewhere in the literature (Jungqvist et al. 2014; Oni et al. 2014, 2015, 2016)

\section{Results}

\subsection{Bias correction and RCM ensemble projections}

Bias correction was needed as the uncorrected RCM ensemble median showed limited agreement with the observed air temperature and precipitation series (Supp 3). The match between the RCM ensemble median and the observed series was improved when bias correction was applied to each of the RCMs to reflect local conditions in Svartberget. However, the RCM ensemble median fit air temperature better than precipitation. Result showed a possibility of increasing annual precipitation and mean temperature overall. Within the 25 th and 75 th percentile, annual precipitation could change by $2-27 \%$ (ensemble median $=17 \%$ ) and average air temperature could increase by $2.8-5.0{ }^{\circ} \mathrm{C}$ (ensemble median $=3.7^{\circ} \mathrm{C}$ ). The largest projected changes occur in winter months.

\subsection{Simulation of soil temperature}

Comparison of historical soil temperature profiles showed negligible differences between riparian and upland soils during winter (Fig. 2). However, temperatures differed in the growing season where upland soils were about $0.4{ }^{\circ} \mathrm{C}$ warmer in the topmost layer $\left(0.3{ }^{\circ} \mathrm{C}\right.$ warmer in middle). The bottom layer in the upland soil was also about $0.3{ }^{\circ} \mathrm{C}$ warmer than the riparian soil during the growing season despite slight differences between depths $(50$ vs. $60 \mathrm{~cm})$. Upland soils also warmed up earlier (April) compared to riparian soil (May).

The model successfully simulated the inter-annual patterns of below surface soil temperature in both the upland and riparian soil profiles (Fig. 3). However, the model 
Fig. 2 Comparison of observed soil temperature in upland and riparian upper (a), middle (b), and bottom (c) soil layers. Note that $R$ denotes riparian soil profile while $U$ represents upland soil profile. Note the difference in depth compared in bottom layer due to data availability
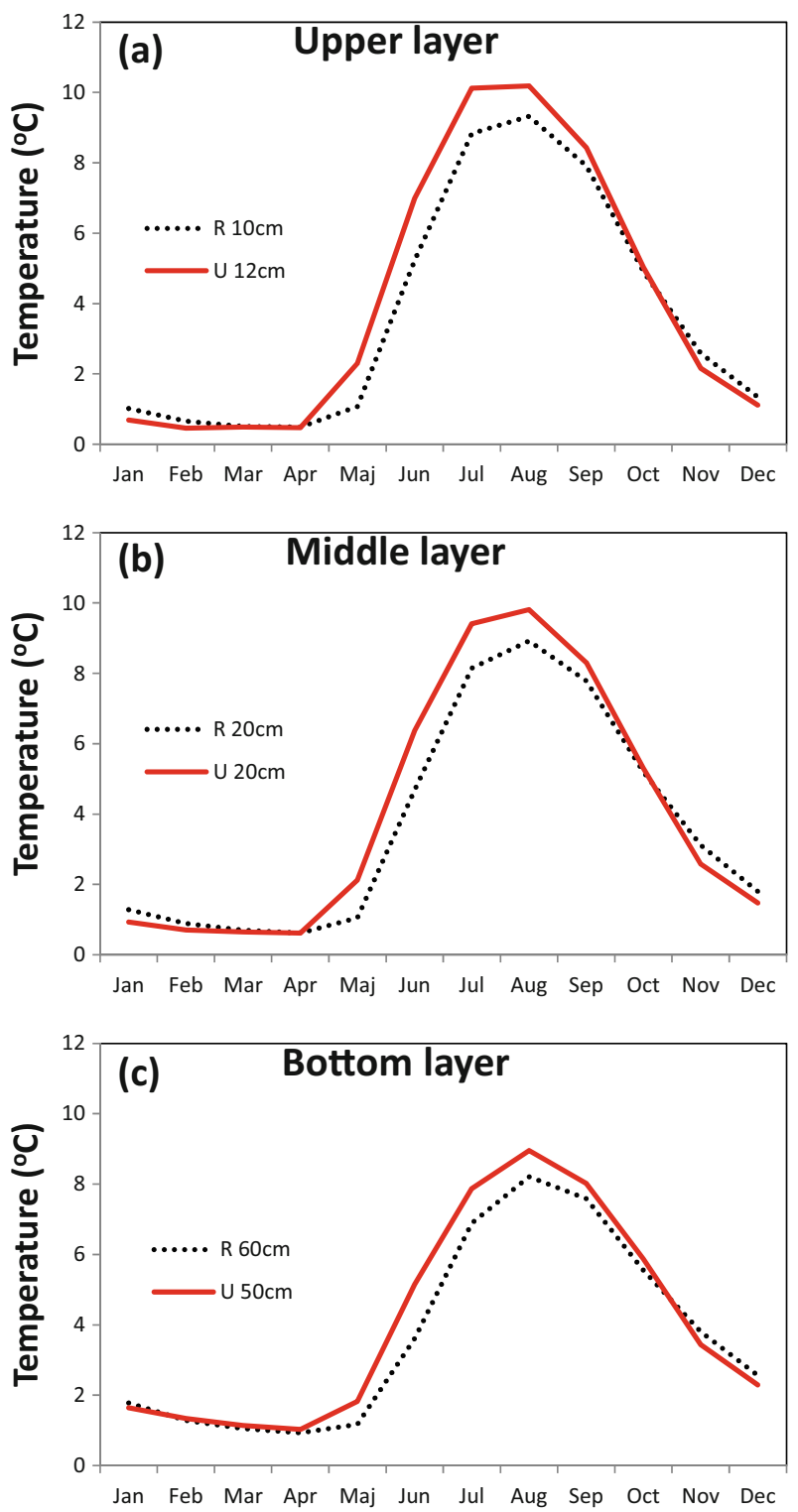

performed better in the upland soil with little difference between the observed and simulated ranges relative to projected series (Table 1). We also observed that the influence of air temperature was stronger in riparian compared to upland soil profiles (Fig. 3). The validation of COUP model with limited independent data available from the riparian profile in 2007 showed that model performed well in reproducing present day soil temperature dynamics with NS values of $0.93,0.90$, and 0.7 in upper, middle, and bottom layers, respectively (Supp 4). When assessed on a seasonal scale (Supp 5), the model performed well in simulating overall temperature dynamics across the gradient of 

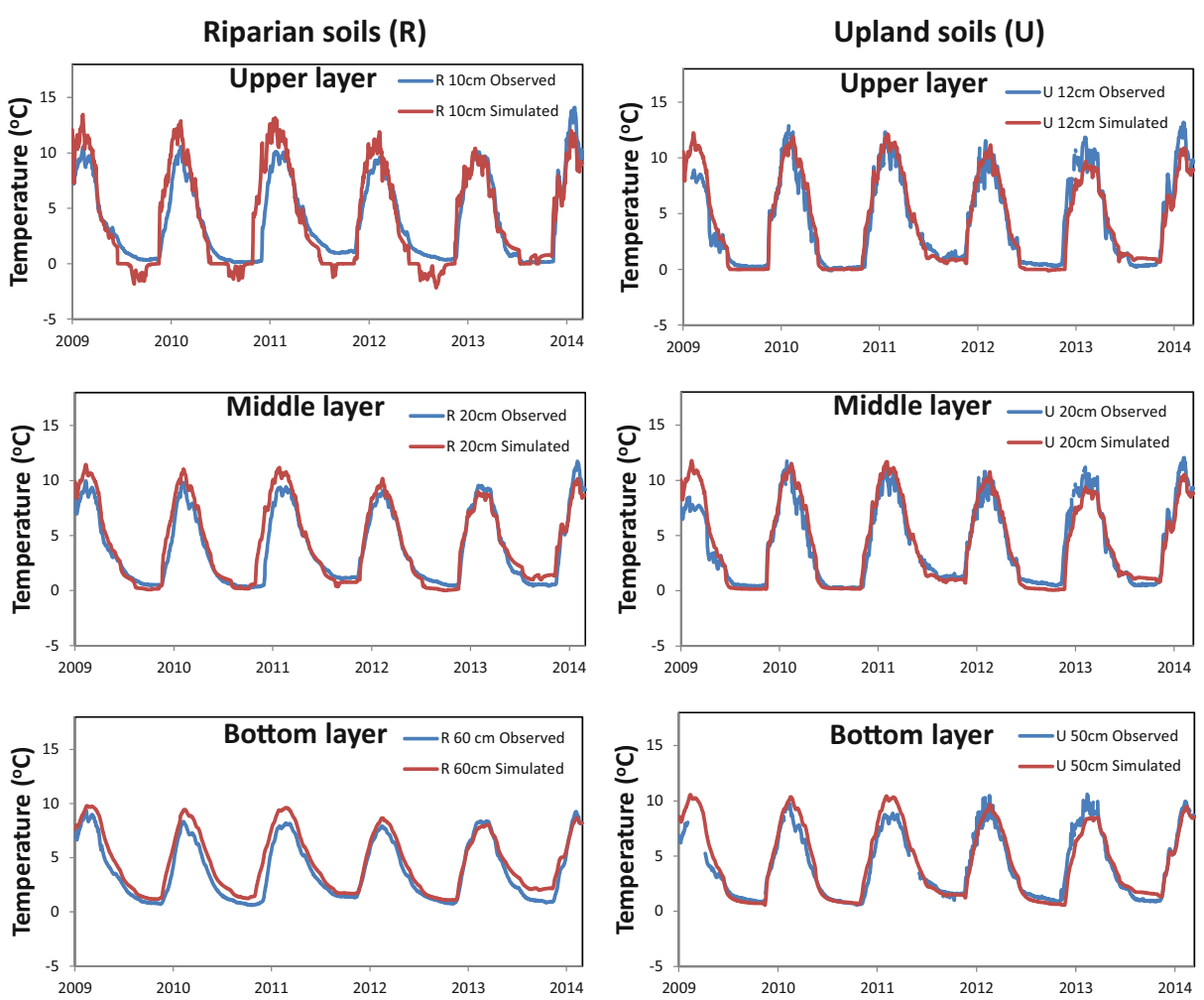

Fig. 3 COUP model calibration (2009-2014) to upper, middle, and lower soil temperature series across a gradient of upland ( $U$; left column) and riparian ( $R$; right column) soils. In riparian soil, upper, middle, and bottom layer represent 10,20 , and $60 \mathrm{~cm}$, respectively, while these mean 12,20 , and $50 \mathrm{~cm}$, respectively in upland soil

soil depths in upland soils. However, large uncertainty existed when simulating riparian soil temperatures due to a discrepancy between the observed and simulated series (highest in topmost layer). This discrepancy was most pronounced during winter when the model simulated colder soil (about $-1{ }^{\circ} \mathrm{C}$ ) in the uppermost layer but a warmer soil $\left(0.7^{\circ} \mathrm{C}\right)$ in the bottom layer. In contrast to the winter months, model overestimated the soil temperature in the snow free season (maximum in August) by up to $1.9^{\circ} \mathrm{C}$ in the riparian upper layer and consistently overestimated by $0.8{ }^{\circ} \mathrm{C}$ in the riparian bottom layer. The discrepancy between observed and simulated soil temperatures was minimal in the upland soil profile (Supp 5).

\subsection{Projection of future soil temperature responses}

The model projected a wider range of possible future soil temperatures in the riparian compared to the upland soil profile (Fig. 4). This translated to a 1.3 to $1.7{ }^{\circ} \mathrm{C}$ rise in riparian soils compared to 1.1 to $1.3{ }^{\circ} \mathrm{C}$ in the upland soil (Table 1) relative to median of present day RCM simulation (1981-2010). Overall, future projections showed that riparian soils might be slightly warmer by up to $0.4{ }^{\circ} \mathrm{C}$ in the upper layer in the future $\left(0.2{ }^{\circ} \mathrm{C}\right.$ in the middle and bottom layer) compared to upland soils. 
Table 1 Summary of model efficiency, present day, and projected soil temperature ranges across upland and riparian soil profiles. $\Delta$ soil $T$ and $\Delta$ autumn soil $T$ represent the annual and autumn soil temperature changes across the profiles

\begin{tabular}{|c|c|c|c|c|c|c|}
\hline & \multicolumn{3}{|c|}{ Upland soils } & \multicolumn{3}{|c|}{ Riparian soils } \\
\hline & Upper & Middle & Bottom & Upper & Middle & Bottom \\
\hline Nash Suttcliffe efficiency & 0.93 & 0.92 & 0.92 & 0.78 & 0.88 & 0.86 \\
\hline Observed range $\left({ }^{\circ} \mathrm{C}\right)$ & $-0.1,13.2$ & $0.2,12.1$ & $0.6,10.6$ & $0.0,14.1$ & $0.3,11.8$ & $0.6,9.4$ \\
\hline Simulated range $\left({ }^{\circ} \mathrm{C}\right)$ & $-0.3,12.5$ & $0.1,11.8$ & $0.3,11.3$ & $-2.0,13.4$ & $0.0,11.5$ & $1.1,9.8$ \\
\hline Projected range $\left({ }^{\circ} \mathrm{C}\right)$ & $4.4,5.7$ & $4.3,5.7$ & $4.3,5.7$ & $4.7,6.0$ & $4.8,6.0$ & $5.1,6.0$ \\
\hline$\Delta$ soil $T\left({ }^{\circ} \mathrm{C}\right)$ & 1.3 & 1.3 & 1.1 & 1.7 & 1.5 & 1.3 \\
\hline$\Delta$ autumn soil $T\left({ }^{\circ} \mathrm{C}\right)$ & 0.6 & 2.0 & 2.0 & 2.2 & 2 & 1.7 \\
\hline
\end{tabular}

In addition to assessments on an annual scale, we also assessed possible future seasonal soil temperature dynamics (Fig. 5). Model projections showed little changes in winter soil temperatures in the middle layer, a colder bottom layer but a slightly warmer upper layer in the upland profile. However, soils could still remain colder in the riparian upper soil layer compared to the present day with little or no change compared to the RCM reference period (1981-2010) in both middle and bottom layers. We also compared the ensemble of future RCM projections (2061-2090) with RCM reference simulations (1981-2010) (Fig. 5). Results showed possibility of warmer soils from summer through autumn months in middle and bottom layers but soil could get a lot warmer in autumn at the topmost upland soil layer. Soil warming increases with a warmer climate and could reached a greater depth in the upland soil. However, RCM ensemble median projections showed that autumn soil temperature could rise by 0.6 to $2.0{ }^{\circ} \mathrm{C}$ in the upland soils versus 1.7 to $2.2{ }^{\circ} \mathrm{C}$ rise in the riparian soils (Table 1). All RCMs projected that soils could begin to warm up earlier in spring (April) compared to the present day (May) in riparian soils and the shift in warming could be more pronounced towards riparian zones (Fig. 5).

\section{Discussion}

Riparian zones are the primary regulators of water quality in the snow-dominated temperate and boreal forest (Blume and Van Meerveld 2015; McClain et al. 2003; Luke et al. 2007; Vidon et al. 2010). How this might shift under changing climate and/or forest management is a subject of ongoing debate (Grillakis et al. 2016; Oni et al. 2015). While most climate change studies examine riparian-upland areas as a lumped entity and base assessments on changes in air temperature, less work has focused on spatial variation of soil temperature responses as a metric of climate change. Evaluating detailed soil temperature responses in the boreal landscape might require significant work due to large heterogeneity of soils even at a local scale. However, such efforts are needed as soil temperature controls the overall biogeochemical and hydrological processes in the aquatic ecosystems. Using the headwater upland-riparian transect in Svartberget with long-term soil temperature profile data as inputs to a process-based modeling exercise such as the one presented here can therefore provide a start for assessing the variations in soil responses needed for a better understanding of the impact of climate change and forest harvesting on water quality in boreal ecozone. 

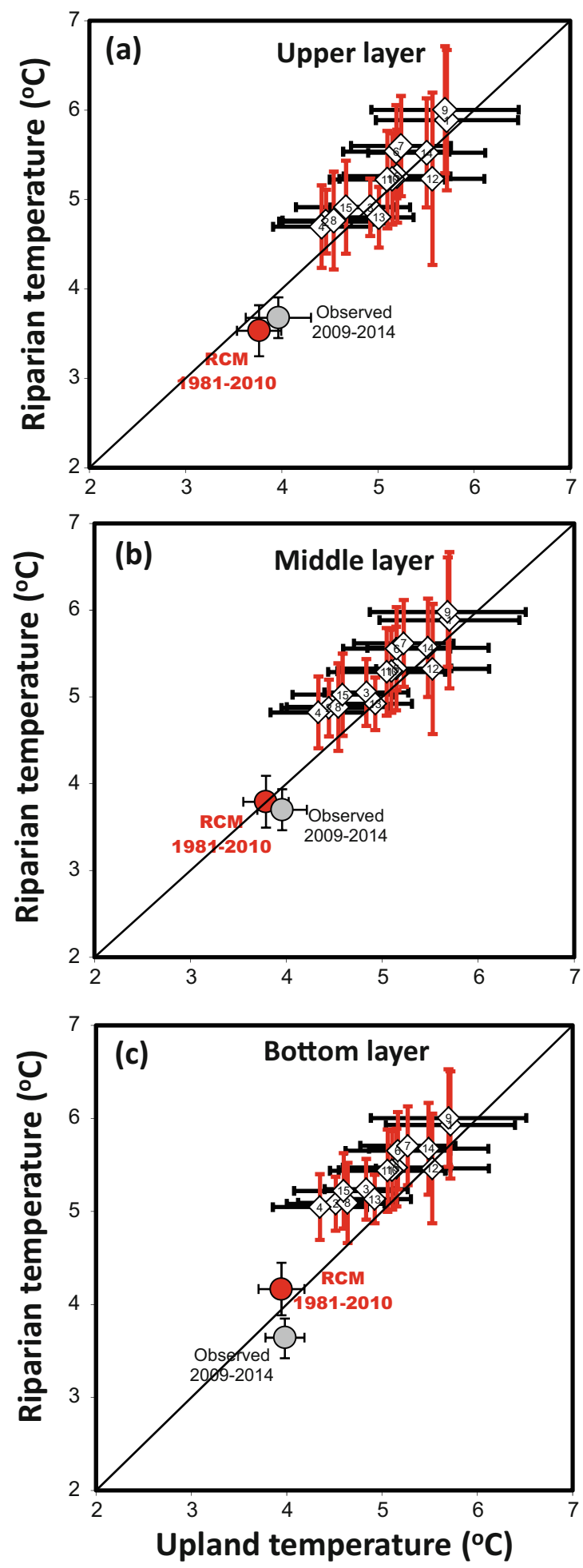
Fig. 4 Comparison of upland-riparian soil temperature responses in upper (a), middle (b), and bottom (c) layers to climate change under the ensemble of present day (RCM 1981-2010) and future conditions (2061-2090). The whiskers show the standard deviation of the annual data

\subsection{Soil temperature responses along upland-riparian transect}

Application of the COUP model successfully simulated soil temperature profiles from upland and riparian zones in the Swedish boreal forest under present day conditions. Better model performance in upland compared to riparian soils is consistent with Jungqvist et al. (2014) who simulated upland soil temperature in a nearby catchment. While the earlier study by Jungqvist et al. (2014) applied their simple model to upland soils, they missed the heterogeneous soil responses to changing climate expected at local scales. Therefore, we focused on the localscale assessment to aid our understanding of how spatial heterogeneity could drive soil temperature response to climate change at much larger scales. Though their simple model projected wider soil temperature range (Supp 6) and can be explained by balancing/ compensatory feedback mechanisms from processes that complex models such as coup model represent. Despite the structural complexity of COUP model that represented many subsurface
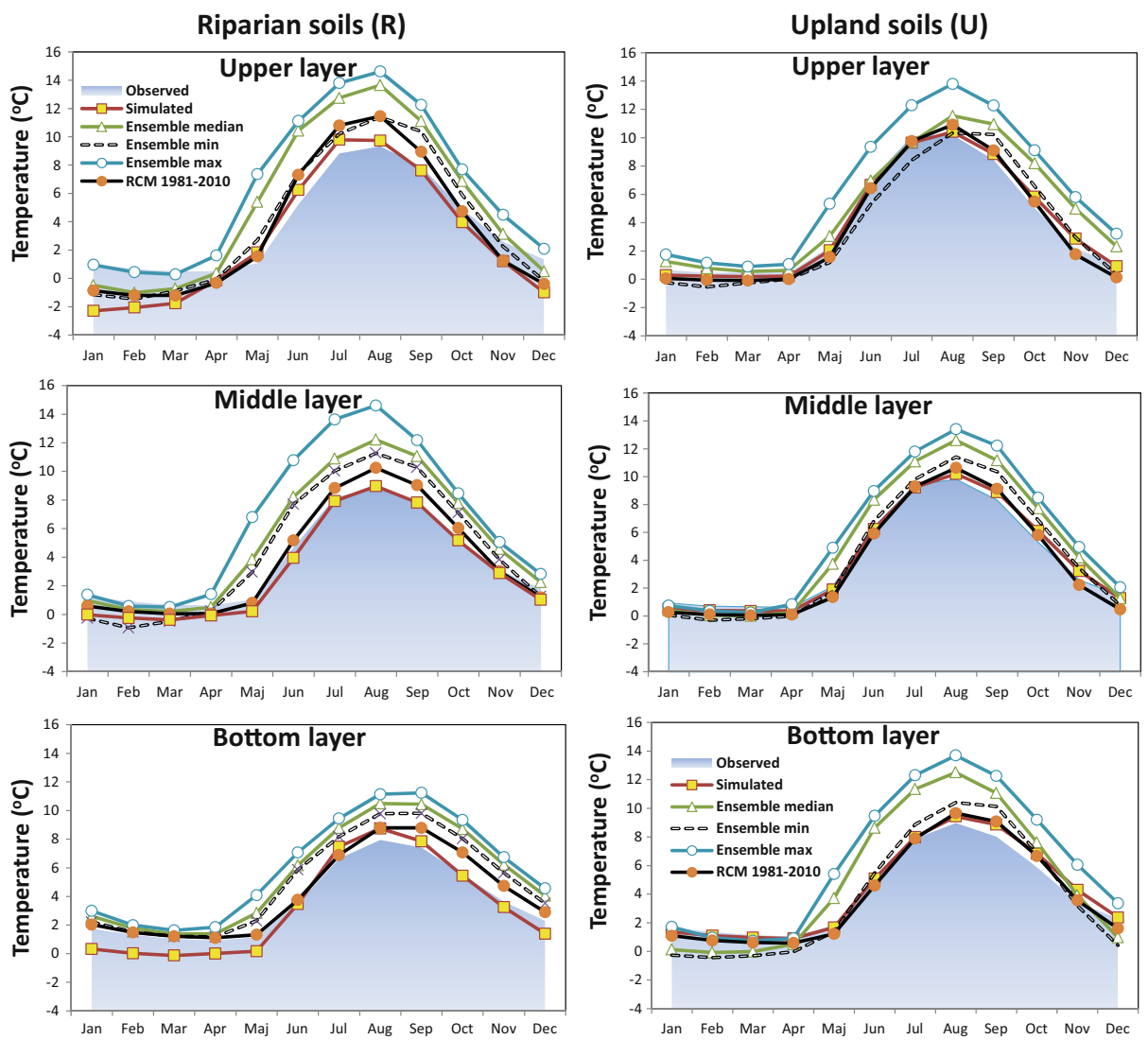

Fig. 5 Seasonal assessments of soil temperature responses to climate change across depth and upland-riparian gradient in Svartberget. In riparian soil ( $R$; column 1), upper, middle, and bottom layer represent 10,20 , and $60 \mathrm{~cm}$, respectively, while they represent 12,20 , and $50 \mathrm{~cm}$, respectively in upland soil ( $U$; column 2 ) 
processes, the model could not simulate the actual surface soil temperature well in either riparian or upland soils (Supp 7). A possible explanation could be the strong influence of air temperature that drives large change in thermal mass in the surface soils. Therefore, deeper influence of air temperature in riparian than upland soils can result from soil moisture gradient that can conduct heat away faster to the subsurface layers. This can have implications in riparian zones as the dominant source layer (Ledesma et al. 2015) can become wider in response to warmer air temperature.

There are numerous reports that climate change will have greater impacts in northern latitudes (Barnett et al. 2005; Brown and Robinson 2011; Euskirchen et al. 2007; Koca et al. 2006). Although, our assumption that current climate conditions may still hold in the future in our RCM projections, it can contribute another degree to the amplification of uncertainty as climate gets warmer in the future (Boberg and Christensen 2012). Our projected increase in precipitation $\left(17 \%\right.$ ) and air temperature (up to $3.7^{\circ} \mathrm{C}$ ) is in line with several other independent studies that projected warmer wetter conditions for snow dominated boreal ecosystems (Brown and Robinson 2011; Mellander et al. 2007; Teutschbein and Seibert 2012). This will have implications for winter snow and spring melt hydrology as dormant season days with air temperature below $0{ }^{\circ} \mathrm{C}$ could be shortened considerably compared to the present-day climatic conditions (Oni et al. 2014, 2016).

Our observation of widespread climate projections showed that there was greater variability in RCM-projected changes in air temperature than soil temperature. This is particularly important as the relationships that exist between air and soil temperature responses to climate change are not linear especially in the dormant seasons. This is evident in our study where the influence of snow cover on winter soil temperature is crucial. Although upland soils might be slightly warmer than the riparian soils overall, this could potentially reverse in the future with a tendency towards decreased snow accumulation. Mellander et al. (2007) previously showed that variability of soil warming was larger in years with least snow cover, although they also showed that forest stand composition and leaf area index can all contribute to earlier soil warming. Therefore, any change in snow fall and snow melt can have large implications on winter and spring soil temperature responses.

\subsection{Implications for the boreal forest ecosystem as a whole}

Inferences drawn from this local-scale assessment showed that soil responses to climate change scenarios could vary greatly along gradient of wetness and soil types at local scale. This will have large implications across the boreal forest as below ground biogeochemical processes are usually slower at temperatures below freezing. However, a rise in soil temperature by $1{ }^{\circ} \mathrm{C}$ can drive decomposition rate by $10 \%$ due to exponential increase in decomposition above $0{ }^{\circ} \mathrm{C}$ (Kirschbaum 1995: Zheng et al. 1993). Projections of slightly colder riparian soils in the winter and warmer soils in the growing season months suggests that riparian soils could become an even more sensitive biogeochemical hotspot in boreal forests (Haei et al. 2013; Ledesma et al. 2016). This can have implications on boreal water quality as future climate change could cause groundwater levels to rise (Lyon et al. 2011) and be in more frequent contact with conductive hydraulic layer. This conductive dominant source layer (Ledesma et al. 2015) can become widened as climate change and can lead to increased mobility of solutes to streams, making riparian to act as a source of pollutant due to cotransportation (Cory et al. 2007). However, riparian soils have also been recognized as sink of pollutants due to its high retention of chemicals (Ledesma et al. 2016; Luke et al. 2007). 
The boreal forest will, for the foreseeable future, continue to be affected by forest clear-cuts to fulfill greener energy initiatives in Europe to combat global climate change (Egnell et al. 2011). These can amplify the decoupling effects of upland-riparian soil processes in the dormant seasons when the impact of change in snow cover is expected to be pronounced in this region. As a result, colder winter soil temperature can alter rates of decomposition and nutrient availability for plant growth (Charles and Dukes 2009; Davidson and Janssens 2006; Fitzhugh et al. 2001). Agreement of RCM on earlier soil warming in the spring implied plausible regime shift in spring melt and extended growing season that can increase carbon and nutrient exports (Charles and Dukes 2009). Such shift in soil thermal regime can alter ecological succession, change in water quality regimes, and more litter productions or more biogeochemically active winter. While boreal forest is currently regarded as net sink of carbon (Kasischke 2000), future climate change can drive soil temperature to a new regime that will reverse this trend as the boreal region become net source of carbon and other carbon-dependent contaminants.

Acknowledgements This study is part of FORMAS ForWater and MISTRA Future Forest research projects aiming at unraveling the effects of climate change and forest managements on forest water quality. This work has also been made possible by the Kempe Foundation and SITES (VR), SKB, and Oscar and Lili Lamm foundation. The ENSEMBLES data was provided by EU FP6 Integrated project ENEMBLES (Contract 505539). We also thank Claudia Teutschbein for providing the bias corrected climate data.

Open Access This article is distributed under the terms of the Creative Commons Attribution 4.0 International License (http:/creativecommons.org/licenses/by/4.0/), which permits unrestricted use, distribution, and reproduction in any medium, provided you give appropriate credit to the original author(s) and the source, provide a link to the Creative Commons license, and indicate if changes were made.

\section{References}

Apps M, Kurz W, Luxmoore R, Nilsson L, Sedjo R, Schmidt R, Vinson T (1993) Boreal forests and tundra. Water Air Soil Pollut 70(1-4):39-53

Batjes NH (1996) Total carbon and nitrogen in the soils of the world. Eur J Soil Sci 47(2):151-163

Barnett TP, Adam JC, Lettenmaier DP (2005) Potential impacts of a warming climate on water availability in snow-dominated regions. Nature 438(7066):303-309

Berghuijs W, Woods R, Hrachowitz M (2014) A precipitation shift from snow towards rain leads to a decrease in streamflow. Nat Clim Chang 4(7):583-586

Beven K, Binley A (1992) The future of distributed models: model calibration and uncertainty prediction. Hydrol Process 6(3):279-298

Blume T, Van Meerveld H (2015) From hillslope to stream: methods to investigate subsurface connectivity. Wiley Interdisciplinary Reviews: Water 2(3):177-198

Boberg F, Christensen JH (2012) Overestimation of Mediterranean summer temperature projections due to model deficiencies. Nat Clim Chang 2(6):433-436

Bond-Lamberty B, Wang C, Gower ST (2005) Spatiotemporal measurement and modeling of stand-level boreal forest soil temperatures. Agric For Meteorol 131(1):27-40

Brown R, Robinson D (2011) Northern Hemisphere spring snow cover variability and change over 1922-2010 including an assessment of uncertainty. Cryosphere 5(1):219-229

Charles H, Dukes JS (2009) Effects of warming and altered precipitation on plant and nutrient dynamics of a New England salt marsh. Ecol Appl 19:1758-1773

Cory RM, McKnight DM, Chin YP, Miller P, Jaros CL (2007) Chemical characteristics of fulvic acids from Arctic surface waters: Microbial contributions and photochemical transformations. J Geophys Res Biogeosci 112(G4):G04551. doi:10.1029/2006/JG000343

Davidson EA, Janssens IA (2006) Temperature sensitivity of soil carbon decomposition and feedbacks to climate change. Nature 440(7081):165-173

Egnell G, Laudon H, Rosvall O (2011) Perspectives on the potential contribution of Swedish forests to renewable energy targets in Europe. Forests 2(2):578-589 
Euskirchen E, McGuire A, Chapin FS (2007) Energy feedbacks of northern high-latitude ecosystems to the climate system due to reduced snow cover during 20th century warming. Glob Chang Biol 13(11):2425-2438

Fitzhugh RD, Driscoll CT, Groffman PM, Tierney GL, Fahey TJ, Hardy JP (2001) Effects of soil freezing disturbance on soil solution nitrogen, phosphorus, and carbon chemistry in a northern hardwood ecosystem. Biogeochemistry 56(2):215-238

Fröberg M, Berggren D, Bergkvist B, Bryant C, Mulder J (2006) Concentration and fluxes of dissolved organic carbon (DOC) in three Norway spruce stands along a climatic gradient in Sweden. Biogeochemistry 77(1):1-23

Grabs T, Bishop K, Laudon H, Lyon SW, Seibert J (2012) Riparian zone hydrology and soil water total organic carbon (TOC): implications for spatial variability and upscaling of lateral riparian TOC exports. Biogeosciences 9(10):3901-3916

Grillakis MG, Koutroulis AG, Papadimitriou LV, Daliakopoulos IN, Tsanis IK (2016) Climate-induced shifts in global soil temperature regimes. Soil Sci 181(6):264-272

Gustafsson D, Lewan E, Jansson P-E (2004) Modeling water and heat balance of the boreal landscapecomparison of forest and arable land in Scandinavia. J Appl Meteorol 43(11):1750-1767

Haei M, Öquist MG, Kreyling J, Ilstedt U, Laudon H (2013) Winter climate controls soil carbon dynamics during summer in boreal forests. Environ Res Lett 8(2):024017

Henry HA (2008) Climate change and soil freezing dynamics: historical trends and projected changes. Clim Chang 87(3-4):421-434

Hollesen J, Elberling B, Jansson P-E (2011) Future active layer dynamics and carbon dioxide production from thawing permafrost layers in Northeast Greenland. Glob Chang Biol 17(2):911-926

Jansson P, Karlberg L (2011) COUP manual: coupled heat and mass transfer model for soil-plant-atmosphere systems technical manual for the CoupModel. Royal Institute of Technology, Stockholm, pp 1-453

Jansson P-E (2012) CoupModel: model use, calibration, and validation. Trans ASABE 55(4):1337-1346

Jencso KG, McGlynn BL, Gooseff MN, Bencala KE, Wondzell SM (2010) Hillslope hydrologic connectivity controls riparian groundwater turnover: implications of catchment structure for riparian buffering and stream water sources. Water Resour Res 46(10). doi:10.1029/2009WR008818

Jungqvist G, Oni SK, Teutschbein C, Futter MN (2014) Effect of climate change on soil temperature in Swedish boreal forests. PLoS One 9(4):e93957

Karlsson IB, Sonnenborg TO, Jensen KH, Refsgaard JC (2014) Historical trends in precipitation and stream discharge at the Skjern River catchment, Denmark. Hydrol Earth Syst Sci 18(2):595-610

Kasischke ES (2000) Boreal ecosystems in the global carbon cycle. In fire, climate change, and carbon cycling in the boreal forest. Springer, pp 19-30, New York 9446

Kang S, Kim S, Oh S, Lee D (2000) Predicting spatial and temporal patterns of soil temperature based on topography, surface cover and air temperature. For Ecol Manag 136(1):173-184

Kirschbaum MU (1995) The temperature dependence of soil organic matter decomposition, and the effect of global warming on soil organic C storage. Soil Biol Biochem 27(6):753-760

Koca D, Smith B, Sykes MT (2006) Modelling regional climate change effects on potential natural ecosystems in Sweden. Clim Chang 78(2-4):381-406

Kreyling J, Haei M, Laudon H (2013) Snow removal reduces annual cellulose decomposition in a riparian boreal forest. Can J Soil Sci 93(4):427-433

Kurylyk B, Bourque C-A, MacQuarrie K (2013) Potential surface temperature and shallow groundwater temperature response to climate change: an example from a small forested catchment in east-central New Brunswick (Canada). Hydrol Earth Syst Sci 17(7):2701-2716

Laudon H, Ottosson-Löfvenius M (2015) Adding snow to the picture-providing complementary winter precipitation data to the Krycklan catchment study database. Hydrol Process 30(13):2413-2416

Laudon H, Seibert J, Köhler S, Bishop K (2004) Hydrological flow paths during snowmelt: congruence between hydrometric measurements and oxygen 18 in meltwater, soil water, and runoff. Water Resour Res 40(3), W03102. doi:10.1029/2003WR002455.

Laudon H, Taberman I, Ågren A, Futter M, Ottosson-Löfvenius M, Bishop K (2013) The Krycklan Catchment Study - a flagship infrastructure for hydrology, biogeochemistry, and climate research in the boreal landscape. Water Resour Res 49(10):7154-7158

Ledesma JL, Futter MN, Laudon H, Evans CD, Köhler SJ (2016) Boreal forest riparian zones regulate stream sulfate and dissolved organic carbon. Sci Total Environ 560:110-122

Ledesma JL, Grabs T, Bishop KH, Schiff SL, Köhler SJ (2015) Potential for long-term transfer of dissolved organic carbon from riparian zones to streams in boreal catchments. Glob Chang Biol 21(8):2963-2979

Luke SH, Luckai NJ, Burke JM, Prepas EE (2007) Riparian areas in the Canadian boreal forest and linkages with water quality in streams. Environ Rev 15:79-97

Lyon SW, Grabs T, Laudon H, Bishop KH, Seibert J (2011) Variability of groundwater levels and total organic carbon in the riparian zone of a boreal catchment. J Geophys Res Biogeosci 116(G1), G01020. doi:10.1029 /2010JG001452. 
McClain ME, Boyer EW, Dent CL, Gergel SE, Grimm NB, Groffman PM, Mayorga E (2003) Biogeochemical hot spots and hot moments at the interface of terrestrial and aquatic ecosystems. Ecosystems 6(4):301-312

Mellander P-E, Ottosson-Löfvenius M, Laudon H (2007) Climate change impact on snow and soil temperature in boreal Scots pine stands. Clim Chang 85(1-2):179-193

Metzger C, Jansson P-E, Lohila A, Aurela M, Eickenscheidt T, Belelli-Marchesini L, Drösler M (2015) CO2 fluxes and ecosystem dynamics at five European treeless peatlands-merging data and process oriented modeling. Biogeosciences 12(1):125-146

Nordén L g (1991) Soil water characteristics in glacial till at two forest sites in Sweden. Scand J For Res 6(1-4): 289-304

Oni S, Futter M, Bishop K, Kohler S, Ottosson-Lofvenius M, Laudon H (2013) Long-term patterns in dissolved organic carbon, major elements and trace metals in boreal headwater catchments: trends, mechanisms and heterogeneity. Biogeosciences 10(4):2315-2330

Oni S, Futter M, Ledesma J, Teutschbein C, Buttle J, Laudon H (2016) Using dry and wet year hydroclimatic extremes to guide future hydrologic projections. Hydrol Earth Syst Sci 20(7):2811-2825

Oni SK, Futter MN, Teutschbein C, Laudon H (2014) Cross-scale ensemble projections of dissolved organic carbon dynamics in boreal forest streams. Clim Dyn 42(9-10):2305-2321

Oni SK, Tiwari T, Ledesma JL, Ågren AM, Teutschbein C, Schelker J et al (2015) Local-and landscape-scale impacts of clear-cuts and climate change on surface water dissolved organic carbon in boreal forests. Journal of Geophysical Research: Biogeosciences 120(11):2402-2426

Oztas T, Fayetorbay F (2003) Effect of freezing and thawing processes on soil aggregate stability. Catena 52(1): $1-8$

Pan Y, Birdsey RA, Fang J, Houghton R, Kauppi PE, Kurz WA, Canadell JG (2011) A large and persistent carbon sink in the world's forests. Science 333(6045):988-993

Peralta-Tapia A, Sponseller RA, Ågren A, Tetzlaff D, Soulsby C, Laudon H (2015) Scale-dependent groundwater contributions influence patterns of winter baseflow stream chemistry in boreal catchments. Journal of Geophysical Research: Biogeosciences 120(5):847-858

Petrone K, Buffam I, Laudon H (2007) Hydrologic and biotic control of nitrogen export during snowmelt: a combined conservative and reactive tracer approach. Water Resour Res 43(6), W06420. doi:10.1029/2006 WR005286.

Pumpanen J, Heinonsalo J, Rasilo T, Villemot J, Ilvesniemi H (2012) The effects of soil and air temperature on $\mathrm{CO} 2$ exchange and net biomass accumulation in Norway spruce, Scots pine and silver birch seedlings. Tree Physiol 32:724-736

Rankinen K, Karvonen T, Butterfield D (2004) A simple model for predicting soil temperature in snow-covered and seasonally frozen soil: model description and testing. Hydrol Earth Syst Sci Discuss 8(4):706-716

Solomon S (2007) Climate change 2007-the physical science basis: working group I contribution to the fourth assessment report of the IPCC (Vol. 4): Cambridge University Press

Strömgren M, Linder S (2002) Effects of nutrition and soil warming on stemwood production in a boreal Norway spruce stand. Glob Chang Biol 8(12):1194-1204

Teutschbein C, Seibert J (2012) Bias correction of regional climate model simulations for hydrological climatechange impact studies: review and evaluation of different methods. J Hydrol 456:12-29

Thakur MP, Reich PB, Eddy WC, Stefanski A, Rich R, Hobbie SE, Eisenhauer N (2014) Some plants like it warmer: increased growth of three selected invasive plant species in soils with a history of experimental warming. Pedobiologia (Jena) 57:57-60

Tierney GL, Fahey TJ, Groffman PM, Hardy JP, Fitzhugh RD, Driscoll CT (2001) Soil freezing alters fine root dynamics in a northern hardwood forest. Biogeochemistry 56(2):175-190

Vidon P, Allan C, Burns D, Duval TP, Gurwick N, Inamdar S, Sebestyen S (2010) Hot spots and hot moments in riparian zones: potential for improved water quality management. J Am Water Resour Assoc 46:278-298. doi:10.1111/j.1752-1688.2010.00420.x

Winterdahl M, Futter M, Köhler S, Laudon H, Seibert J, Bishop K (2011) Riparian soil temperature modification of the relationship between flow and dissolved organic carbon concentration in a boreal stream. Water Resour Res 47(8), W085232. doi:10.1029/2010WR010235.

Zheng D, Hunt ER Jr, Running SW (1993) A daily soil temperature model based on air temperature and precipitation for continental applications. Clim Res 2(3):183-191 